\title{
Pengaruh Sosialisasi, Sanksi, dan Kepercayaan terhadap Kepatuhan Wajib Pajak dalam Membayar Pajak Pph Pasal 21
}

\author{
Meiliyah Ariani ${ }^{1}$, Defrianto ${ }^{2}$, Zulhawati $^{3}$ \\ 1.2 Universitas Prof. Dr. Moestopo (Beragama) Jakarta, Indonesia \\ ${ }^{3}$ Universitas Teknologi Yogyakarta, Yogykarta, Indonesia, Jalan Ringroad Utara, Daerah Istimewa Yogyakarta
}

\section{N F O ART I KEL A B S TRA $\boldsymbol{A}$ T}

JEL Classification:

$H 26$

$H 83$

\section{Keywords:}

Socialization Taxes,

Penalties Tax,

Trust Officers Against Taxes,

Taxes Pay Individual

Compliance.
This study aims to determine the effect of Socialization Taxes, Penalties Tax, and Trust Officers Against Taxes on Individual Taxpayer Compliance in Tax Paying Income Tax Article 21 (Empirical Study KPP Pratama Jakarta Kebayoran Lama). Data were obtained from the questionnaire (primary). analysis of the data model used in this research is multiple regression analysis. Sampling was done by accidental sampling method (Convenience Sampling). Based on the results of data analysis using SPSS 23 shows that the t-test results prove the hypothesis that socialization tax and penalties tax have no effect, while the effect on the confidence of taxpayer compliance in paying taxes Income Tax Article 21 on KPP Pratama Jakarta Kebayoran Lama. F-test results prove the hypothesis that socialization tax, penalties tax, and the trust officers against taxes has a positive influence on tax compliance in paying taxes Income Tax Article 21 on KPP Pratama Jakarta Kebayoran Lama.

\section{A B S T R A K}

Penelitian ini bertujuan untuk mengetahui Pengaruh Sosialisasi Pajak, Sanksi Pajak, dan Kepercayaan terhadap Aparat Pajak dalam Kepatuhan Individu Wajib Pajak Membayar Pajak PPh pasal 21 (Studi Empiris KPP Pratama Jakarta Kebayoran Lama). Data penelitian diperoleh dari kuesioner (primer). analisis model data yang digunakan dalam penelitian ini adalah analisis regresi berganda. Pengambilan sampel dilakukan dengan metode accidental sampling (Convenience Sampling). Berdasarkan hasil analisis data dengan menggunakan SPSS 23 menunjukkan bahwa hasil hipotesis t-test membuktikan bahwa sosialisasi pajak dan sanksi pajak tidak berpengaruh, sedangkan kepercayaan terhadap aparat pajak berpengaruh pada kepatuhan dari wajib pajak dalam membayar pajak PPh pasal 21 di KPP Pratama Jakarta Kebayoran Lama. Hasil hipotesis f-test membuktikan bahwa sosialisasi pajak, sanksi pajak, dan kepercayaan terhadap aparat pajak memiliki pengaruh positif pada kepatuhan wajib pajak dalam membayar pajak PPh pasal 21 di KPP Pratama Jakarta Kebayoran Lama.

\section{Pendahuluan}

Pajak memegang peranan yang penting sebagai sumber andalan utama penerimaan negara dalam APBN selain minyak dan gas bumi, yang bertujuan untuk meningkatkan kesejahteraan rakyat melalui pembangunan dan peningkatan sarana publik. Pajak berfungsi sebagai alat untuk mengumpulkan dana (budgetair) yang akan digunakan untuk membiayai berbagai macam 
pengeluaran pemerintah. Selama 5 tahun terakhir, penerimaan perpajakan rata-rata hampir sekitar $70 \%$ dari total pendapatan negara. Penerimaan perpajakan membutuhkan sistem pengelolaan serta peningkatan pengawasan dan pelayanan yang semakin prima sehingga penerimaan perpajakan dapat dioptimalkan.

Realisasi penerimaan pajak tahun 2014 mencapai Rp 984.903,21 miliar. Dari target penerimaan pajak yang ditetapkan sesuai APBN-P 2014 sebesar Rp 1.072.376,37 miliar, realisasi penerimaan pajak mencapai $91,84 \%$. Jika dibandingkan dengan periode yang sama di tahun 2013, realisasi penerimaan pajak di tahun 2014 ini mengalami pertumbuhan yang cukup baik di sektor tertentu, namun juga mengalami penurunan pertumbuhan di sektor PBB -7,22\% dan PPh Migas $-1,47 \%$. Kondisi tersebut diatas mengakibatkan beban tugas yang di emban oleh aparat perpajakan akan semakin berat. Realisasi penerimaan pajak untuk tahun 2014 dapat dilihat pada tabel.1

Setelah reformasi perpajakan Officialassessment system sudah tidak berlaku lagi dan diberlakukan self-assessment system. Fakta yang terjadi, kewenangan yang diberikan tidak sepenuhnya dijalankan oleh wajib pajak orang pribadi untuk memenuhi kewajiban perpajakannya, justru membuat wajib pajak tersebut menjadi lebih mudah untuk menyelewengkan kewajiban perpajakannya.

Pencapaian persentase rasio kepatuhan penyampaian SPT Tahunan PPh dalam 5 tahun terakhir selalu berada di bawah target yang ditetapkan. Untuk lebih jelasnya dapat dilihat pada tabel. 2

Berdasarkan data tersebut diketahui bahwa dengan kata lain dari dua orang wajib pajak yang wajib menyampaikan SPT tahunan hanya 1 orang yang menyampaikan SPT Tahunan. Tentu saja kondisi ini tidak menguntungkan bagi pemerintah. Kondisi rendahnya kepatuhan wajib pajak tersebut tentu saja berakibat kepada sulit tercapainya target penerimaan pajak (www. pajak.go.id). Hal ini menunjukkan bahwa terdapat indikasi motivasi wajib pajak orang pribadi yang rendah untuk membayar pajak. Pembahasan mengenai hal ini penting dilakukan untuk terus meningkatkan kepatuhan wajib pajak.

Tabel 1. Realisasi Penerimaan Pajak s/d 31 Desember 2014 (Miliar Rupiah)

\begin{tabular}{lllll}
\hline \multirow{2}{*}{ Jenis Pajak } & \multirow{2}{*}{ APBN-P 2014 } & \multicolumn{2}{c}{ Realisasi s.d 31 Des } & \multirow{2}{*}{2013} \\
\cline { 3 - 4 } & & $417.656,59$ & $458.692,28$ & 9,83 \\
\hline PPh Non Migas & $485.976,87$ & $384.628,91$ & $408.995,74$ & 6,34 \\
PPN \& PPnBM & $475.587,18$ & $25.302,49$ & $23.475,71$ & $-7,22$ \\
PBB & $21.742,91$ & $4.933,63$ & $6.293,13$ & 27,56 \\
Pajak Lainnya & $5.179,61$ & $832.521,62$ & $897.456,86$ & 7,8 \\
Total Non PPh Migas & $988.486,57$ & $88.747,47$ & $87.446,35$ & $-1,47$ \\
PPh Migas & $83.889,80$ & & & \\
Total termasuk PPh & & & $984.903,21$ & 6,91 \\
Migas & $1.072 .376,37$ & $921.269,09$ & & \\
\hline
\end{tabular}

Sumber: Laporan Kinerja Kementrian Keuangan 2014

Tabel 2. Rasio Kepatuhan Penyampaian SPT PPh Tahun 2010-2014 (Satuan Ribu)

\begin{tabular}{llllll}
\hline Uraian & 2010 & 2011 & 2012 & 2013 & 2014 \\
\hline WP Terdaftar & 15.911 & 19.112 & 22.564 & 24.886 & 26.918 \\
WP Wajib SPT & 14.101 & 17.694 & 17.659 & 17.731 & 18.357 \\
SPT Tahunan PPh & 8.202 & 9.332 & 9.482 & 10.781 & 10.851 \\
Rasio Kepatuhan & $58,16 \%$ & $52,74 \%$ & $53,70 \%$ & $60,80 \%$ & $58,73 \%$ \\
Target Rasio & $62,50 \%$ & $62,50 \%$ & $62,50 \%$ & $65,00 \%$ & $70,00 \%$ \\
\hline
\end{tabular}

Sumber: Laporan Kinerja Kementrian Keuangan 2014. 
Beberapa faktor-faktor seperti sosialisasi pajak, sanksi pajak, dan kepercayaan terhadap aparat pajak memiliki kemungkinan berpengaruh terhadap wajib pajak dalam membayar pajak $\mathrm{PPh}$ pasal 21.

Penelitian ini bertujuan untuk menguji dan memperoleh bukti empiris mengenai pengaruh sosialisasi, sanksi, dan kepercayaan secara partial maupun secara simultan terhadap kepatuhan wajib pajak dalam membayar pajak $\mathrm{PPh}$ pasal 21. Penelitian ini juga diharapkan dapat memberi informasi yang dibutuh dan bermanfaat bagi akademisi maupun pemerintah berkaitan dengan faktor-faktor yang mempengaruhi kepatuhan wajib pajak dalam membayar pajak $\mathrm{PPh}$ pasal 21.

\section{Telaah Teori Dan Pengembangan Hipotesis}

\section{Kepatuhan Wajib Pajak}

Dalam kamus besar bahasa Indonesia, kepatuhan berarti sifat patuh atau taat. Rutiyaningsih (2011) menyatakan kepatuhan membayar pajak diartikan sebagai suatu keadaan yang mana wajib pajak patuh dan mempunyai kesadaran dalam memenuhi kewajiban perpajakan. Kepatuhan wajib pajak terbagi menjadi dua macam indikator (Lingga, 2013), yaitu:

1. Kepatuhan formal

Wajib pajak yang memiliki kepatuhan formal berarti:

a. Wajib pajak tersebut sudah memahami semua ketentuan perpajakan,

b. Wajib pajak melaksanakan ketentuan perpajakan sesuai dengan undang-undang perpajakannya.

2. Kepatuhan materiaWajib pajak yang memiliki kepatuhan material berarti sudah dapat mengisi SPT dengan baik dan benar serta menyampaikannya tepat waktu. Sama halnya menurut Devano dan Rahayu (2006) kepatuhan perpajakan adalah suatu iklim kepatuhan dan kesadaran pemenuhan kewajiban perpajakan, adapun indikatornya yaitu:

a. Melaporkan SPT tepat waktu,
b. Menghitung pajak terutang,
c. Membayar pajak terutang sesuai dengan jumlahnya,

\section{d. Mengisi SPT secara lengkap}

Menurut UU No. 16 Tahun 2000 tentang ketentuan umum perpajakan menyatakan wajib pajak yang patuh dilihat dari kepatuhan dalam mendaftarkan diri, kepatuhan dalam perhitungan dan pembayaran pajak terutang dan tidak pernah dijatuhi hukuman karena melakukan tindakan pidana. Maka konteks kepatuhan dalam penelitian ini mengandung arti bahwa wajib pajak berusaha untukmematuhiperaturanhukumperpajakanyang berlaku terutama kewajiban membayar pajak. Kepatuhan memenuhi kewajiban perpajakan secara sukarela (voluntary of compliance) merupakan tulang punggung dari self assessment system, dimana wajib pajak bertanggung jawab menetapkan sendiri kewajiban perpajakan kemudian secara akurat dan tepat waktu dalam membayar dan melaporkan pajaknya.

Wajib pajak mengenal istilah Surat Setoran Pajak (SSP) dalam membayar pajaknya. SSP adalah bukti pembayaran atau penyetoran pajak yang telah dilakukan dengan menggunakan formulir atau telah dilakukan dengan cara lain ke kas negara melalui tempat pembayaran yang ditunjuk oleh menteri keuangan (Utami, 2016). Bentuk ketaatan wajib pajak adalah membayar pajak dengan menyampaikan Surat Pemberitahuan (SPT). Menurut Ketentuan Umum dan Tata Cara Perpajakan (Direktorat Jenderal Pajak, 2014) menyebutkan bahwa Surat Pemberitahuan (SPT) adalah surat yang oleh Wajib Pajak (WP) digunakan untuk melaporkan penghitungan dan/atau pembayaran pajak, objek pajak dan/atau bukan objek pajak dan/atau harta dan kewajiban sesuai dengan ketentuan peraturan perundang-undangan perpajakan. Terdapat dua macam Surat Pemberitahuan (SPT) yaitu:

a. SPT Masa adalah Surat Pemberitahuan untuk suatu Masa Pajak.

b. SPT Tahunan adalah Surat Pemberitahuan untuk suatu Tahun Pajak atau Bagian Tahun Pajak. 


\section{Sosialisasi Pajak dan Sanksi Pajak}

Sosialisasi adalah suatu proses dimana orang-orang mempelajari sistem nilai, norma dan pola perilaku yang diharapkan oleh kelompok sebagai bentuk transformasi dari orang tersebut sebagai orang luar menjadi organisasi yang efektif (Basamalah, 2004). Sehingga sosialisasi perpajakan dapat diartikan sebagai suatu upaya dari Direktoral Jenderal Pajak untuk memberikan pengertian, informasi, dan pembinaan kepada masyarakat pada umumnya dan wajib pajak pada khususnya mengenai segala sesuatu yang berhubungan dengan perpajakan.

Sosialisasi perpajakan merupakan upaya dari pihak Direktorat Jendral Pajak yang merupakan salah satu institusi di Kementerian Keuangan untuk memberikan pengertian, informasi dan pembinaan kepada masyarakat pada umumnya dan wajib pajak pada khususnya mengenai segala sesuatu yang berhubungan dengan perpajakan dan perundang undangan (Saraswati, 2012). Kegiatan penyuluhan dan pelayanan pajak memegang peranan penting dalam upaya memasyarakatkan pajak dalam upaya kehidupan berbangsa dan bernegara. Proses pemungutan pajak ini tidak mudah tanpa kesadaran dari masyarakat akan arti pentingnya pajak bagi pembiayaan negara khususnya pembangunan sarana publik. Maka dari itu, melalui Surat Edaran Direktur Jendral Pajak Nomor SE22/PJ./2007 tentang Penyeragaman Sosialisasi Perpajakan Bagi Masyarakat menyatakan bahwa indikator sosialisasi perpajakan terdiri dari:

a. Media Informasi

Sumber informasi tentang pajak banyak bersumber dari media massa. Berdasarkan hal tersebut, maka sebaiknya media informasi lebih banyak digunakan dalam sosialisasi perpajakan, seperti: televisi, koran, spanduk, flyers (poster dan brosur), billboard, dan radio.

b. Slogan

Slogan yang digunakan hendaknya tidak boleh menakut nakuti atau bersifat intimidasi, tetapi lebih bersifat ajakan. Slogan sebaiknya lebih ditekankan kepada kata manfaat pajak yang diperoleh, seperti: Lunasi Pajaknya
Awasi Penggunaannya; Orang Bijak Taat Pajak; Pajak Menyatukan Hati, Bangga Bayar Pajak; Pajak Milik Bersama.

c. Cara penyampaian

Penyampaian informasi perpajakan sebaiknya dilakukan dengan cara kontak langsung kepada masyarakat misalnya melalui seminar, diskusi, dan sejenisnya. Dalam penyampaian informasi tersebut sebaiknya menggunakan bahasa yang sesederhana mungkin dan bukan bersifat teknis, sehingga informasi tersebut dapat diterima dengan baik.

d. Kualitas sumber informasi

Informasi tentang pajak dirasa masih sangat kurang oleh masyarakat. Sumber informasi yang dinilai informatif dan dibutuhkan seperti: call center, penyuluhan, internet, aparat pajak, radio, televisi, dan koran.

e. Materi sosialisasi

Materi sosialisasi yang disampaikan lebih ditekankan pada manfaat pajak, manfaat NPWP dan pelayanan perpajakan di masingmasing unit, serta disampaikan dengan jelas agar mudah dimengerti.

f. Kegiatan penyuluhan

Dalam pelaksanaan kegiatan penyuluhan, yang penting diperhatikan adalah metode yang digunakan adalah metode diskusi, media yang dipergunakan adalah proyektor, materi yang disampaikan adalah pengisian SPT dan pengetahuan perpajakan, penyuluh/ pembicara harus sudah menguasai materi.

Program-program yang telah dilakukan berkaitan dengan kegiatan sosialisasi pajak (www.pajak.go.id), antara lain:

1. Mengadakan penyuluhan-penyuluhan tentang perpajakan,

2. Mengadakan seminar-seminar di berbagai profesi serta pelatihan-pelatihan baik untuk pemerintahan maupun swasta,

3. Memasang spanduk yang bertemakan pajak,

4. Memasang iklan layanan masyarakat di berbagai stasiun televisi,.

5. Mengadakan acara tax goes to campus yang diisikan dengan berbagai acara yang menarik mulai dari debat pajak sampai dengan seminar 
pajak dimana acara tersebut bertujuan untuk menimbulkan pemahaman tentang pajak ke mahasiswa yang dinilai sangat kritis.

Dengan terlaksananya sosialisasi perpajakan yang berkualitas, efektif dan efisien diharapkan dapat meningkatkan kepatuhan wajib pajak dalam menjalankan kewajibannya.

Kata sanksi dalam Kamus Bahasa Indonesia berarti tanggungan (tindakan, hukuman, dan sebagainya) untuk memaksa orang menepati perjanjian atau menaati ketentuan undang-undang. Dalam konteks hukum, sanksi berarti hukuman. Sanksi adalah suatu tindakan berupa hukuman yang diberikan kepada orang yang melanggar peraturan. Sanksi diperlukan agar peraturan dan undang- undang tidak dilanggar.

Menurut Mardiasmo (2011) sanksi perpajakan merupakan jaminan bahwa ketentuan peraturan perundang-undangan perpajakan (norma perpajakan) akan dituruti/ditaati/dipatuhi, atau bisa dengan kata lain sanksi perpajakan merupakan alat pencegah (preventif) agar wajib pajak tidak melanggar norma perpajakan. Dalam undang-undang perpajakan terdapat dua jenis sanksi, berupa sanksi pidana dan administrasi. Ancaman terhadap pelanggaran suatu norma perpajakan ada yang diancam dengan sanksi administrasi saja, ada yang diancam dengan sanksi pidana saja, dan ada pula yang diancam dengan sanksi administrasi dan sanksi pidana.

a. Sanksi administrasi merupakan pembayaran kerugian negara, khususnya yang berupa denda, bunga, dan kenaikan.

b. Sanksi pidana ialah sanksi berupa siksaan atau penderitaan, merupakan suatu alat terakhir atau benteng hukum yang digunakan fiskus agar norma perpajakan dipatuhi.

Perbedaan sanksi administrasi dan sanksi pidana menurut undang-undang perpajakan adalah :

1. Sanksi Administrasi

Macam-macam sanksi administrasi antara lain adalah :

a. Denda, sebesar Rp. 100.000,- apabila Surat Pemberitahuan (SPT) Masa tidak disampaikan sesuai dengan batas waktu yaitu selambat-lambatnya 14 (empat) belas hari setelah bulan takwim berakhir khusus untuk pemungutan Pajak Penghasilan $(\mathrm{PPh})$ Pasal 22 atau paling lambat dua puluh hari setelah akhir Masa Pajak khusus untuk pemungutan PPh Pasal 4 ayat (2), PPh Pasal 21 dan PPh Pasal 23; dan apabila Surat Pemberitahuan Tahunan PPh tidak disampaikan sesuai dengan batas waktu yang ditentukan, dikenakan denda untuk WP Orang Pribadi denda sebesar Rp. 100.000,- .

b. Bunga, sebesar :

1. Sebesar $2 \%$ sebulan untuk selamalamanya 24 bulan atas jumlah pajak yang terutang tidak atau kurang dibayar dalam hal:

a. WP membetulkan sendiri SPT yang mengakibatkan utang pajak menjadi lebih besar sebelum dilakukannya pemeriksaan;

b. PPh dalam tahun berjalan tidak atau kurang dibayar dan/atau dari hasil penelitian SPT terdapat kekurangan pembayaran pajak sebagai akibat salah tulis dan/atau salah hitung;

c. Terdapat kekurangan pajak yang terutang dalam Surat Ketetapan Pajak Kurang Bayar (SKPKB) berdasarkan hasil pemeriksaan atau keterangan lain;

d. Penghitungan sementara pajak yang terutang kurang dari jumlah pembayaran pajak yang sebenarnya terutang akibat diberikan ijin penundaan penyampaian SPT Tahunan.

2. Sebesar $2 \%$ sebulan dari pajak yang kurang dibayar dalam hal Bendahara diperbolehkan mengangsur atau menunda pembayaran pajak.

3. Sebesar $48 \%$ dari jumlah pajak yang tidak atau kurang dibayar, dalam hal WP setelah jangka waktu sepuluh tahun dipidana karena melakukan tindak pidana di bidang perpajakan berdasarkan putusan Pengadilan yang telah memperoleh kekuatan hukum tetap. 
4. Sebesar $2 \%$ sebulan dihitung dari jatuh tempo pembayaran sampai dengan tanggal pembayaran dan bagian dari bulan dihitung penuh satu bulan, apabila pembayaran atau penyetoran yang terutang untuk suatu saat atau masa dilakukan setelah jatuh tempo pembayaran atau penyetoran.

c. Kenaikan, sebesar :

$50 \%$ dari PPh yang tidak atau kurang dibayar dalam satu tahun pajak akibat SPT tidak disampaikan dalam jangka waktu yang telah ditentukan dan setelah ditegur secara tertulis tidak disampaikan pada waktunya sebagaimana ditentukan dalam Surat Teguran.

1. Sebesar $100 \%$ dari jumlah PPh yang tidak atau kurang dipotong, tidak atau kurang dipungut, tidak atau kurang disetorkan, dan dipotong atau dipungut tetapi tidak atau kurang disetorkan.

2. Sebesar $100 \%$ dari jumlah kekurangan pajak yang terutang dalam Surat Ketetapan Pajak Kurang Bayar Tambahan dalam hal ditemukan data baru dan/atau data yang semula belum terungkap dari WP yang menyebabkan penambahan jumlah pajak yang terutang.

3. Sanksi administrasi berupa denda $150 \%$ dari pajak yang kurang dibayar, dikenakan terhadap WP yang atas kemauannya sendiri membetulkan SPT setelah dilakukan pemeriksaan tetapi belum dilakukan penyidikan;

4. Sanksi administrasi berupa kenaikan sebesar 200\% dari pajak yang kurang dibayar, dikenakan terhadap WP yang karena kealpaannya tidak menyampaikan SPT atau menyampaikan SPT tetapi isinya tidak benar atau tidak lengkap dan dapat merugikan negara.

Sanksi pidana dapat diterapkan dalam hal :

a. WP karena kealpaannya tidak menyampaikan SPT Tahunan atau menyampaikan tetapi isinya tidak benar atau tidak lengkap, sehingga dapat menimbulkan kerugian pendapatan negara diancam pidana kurungan selama-lamanya satu tahun dan denda setinggi-tingginya 2 kali jumlah pajak yang terutang/tidak atau kurang dibayar (Pasal 38);

b. WP dengan sengaja tidak menyampaikan SPT Tahunan atau menyampaikan tetapi isinya tidak benar atau tidak lengkap/ sehingga dapat menimbulkan kerugian pendapatan Negara. Diancam pidana penjara selama-lamanya 6 (enam) tahun dan denda setinggi-tingginya 4 kali jumlah pajak yang terutang yang tidak atau kurang dibayar (pasal 39);

c. WP melakukan percobaan untuk menyampaikan SPT Tahunan dan atau keterangan yang isinya tidak benar atau tidak lengkap dalam rangka mengajukan restitusi atau melakukan kompensasi pajak dipidana dengan pidana penjara selama-lamanya 6 (enam) tahun dan denda setinggi- tingginya 4 kali jumlah restitusi yang dimohon/atau kompensasi yang dilakukan oleh WP.

d. WP bukan PKP tetapi menerbitkan faktur pajak. WP tertentu yang dikecualikan dari sanksi administrasi berupa denda karena tidak menyampaikan surat pemberitahuan tepat waktu adalah WP Non Efektif

(Pasal 7 ayat (2) KMK Nomor: 537/ KMK:04/2000).

Wajib pajak akan memenuhi pembayaran pajak bila memandang sanksi perpajakan akan lebih banyak merugikannya (Jatmiko, 2006).

\section{Kepercayaan Terhadap Aparat Pajak}

Kepercayaan adalah ekspektasi yang dipegang oleh individu bahwa ucapan seseorang dapat diandalkan. Kelompok terpercaya perlu memilikiintegritastinggidandapatdipercaya,yang diasosiasikan, dengan kualitas yaitu: konsisten, kompeten, jujur, adil, bertanggungjawab, suka membantu dan baik (Yulianto dan Waluyo, 2004). Aparat pajak merupakan pegawai pemerintah yang diberi kewenangan untuk melaksanakan tugas pemungutan pajak (Sulistyowati, 2012). Kepercayaan terhadap Aparat Pajak didefinisikan sebagai suatu ekspektasi wajib pajak terhadap ucapan dan tindakan aparat pajak yang dapat 
diandalkan dalam melayani, membantu, mengurus, atau menyiapkan segala keperluan yang dibutuhkan wajib pajak.

Menurut Robbins (2006) kepercayaan adalah ekspektasi atau pengharapan positif bahwa orang lain tidak akan bertindak oportunistik, baik melalui kata-kata, tindakan, ataupun keputusan. Istilah oportunistik mengacu pada risiko dan kerawanan bawaan di dalam hubungan berbasis kepercayaan. Pada dasarnya kepercayaan memberikan peluang untuk kecewa atau dimanfaatkan orang lain. Menurut Robbins (2006) terdapat lima dimensi kunci (indikator) yang melandasi konsep kepercayaan, yaitu:

a. Integritas

Integritas merujuk pada kejujuran dan keadaan yang sebenarnya. Dalam dimensi ini, integritas aparat pajak tercermin dalam kejujuran, tanggung jawab dan kesesuaian setiap tindakan dengan kode etik pegawai pajak yang berlaku.

b. Kompetensi

Kompetensi merupakan pengetahuan, keahlian teknis dankecerdasaninterpesonal (kecerdasan sosial dalam menjalin hubungan yang baik dan menangani permasalahan). Kompetensi aparat pajak diukur dari pengetahuan maupun keterampilan teknis yang dimiliki oleh aparat pajak dalam upayanya untuk melayani setiap kepentingan wajib pajak.

c. Konsistensi

Konsistensi berkaitan dengan dapat dipercaya, dapat diramalkan, dan pandangan yang baik dalam menangani sesuatu. Konsistensi aparat pajak dapat dilihat dari kesesuaian dalam berjanji terkait manfaat pajak dengan realita yang ada di masyarakat dan konsisten dalam menangani permasalahan dan keluhan yang dialami oleh wajib pajak.

d. Loyalitas

Loyalitas merujuk kepada kepatuhan dan kesetiaan. Kepercayaan masyaratkan bahwa individu akan bergantung pada seseorang yang tidak bersifat oportunistik. Dalam hal ini, wajib pajak cenderung akan memiliki kepercayaan dan bertindak positif kepada aparat pajak yang tidak bertindak oportunistik (menguntungkan diri sendiri) serta aparat pajak yang patuh dan setia terhadap undangundang perpajakan.

e. Keterbukaan

Wajib pajak akan memiliki kepercayaan apabila aparat pajak memiliki transparansi dalam aliran masuk dari berbagai sumber penerimaan pajak serta pengelolaan dan pendistribusian dana pajak.

Kepercayaan terhadap aparat pajak tidak lepas dari kualitas aparat pajak dan pelayanannya sebagai upaya pemenuhan kebutuhan wajib pajak dalam rangka pelaksanaan ketentuan perundangundangan. Tujuan pelayanan untuk menjaga kepuasan wajib pajak yang diharapkan dapat meningkatkan kepatuhan wajib pajak. Kepatuhan wajib pajak dalam memenuhi kewajiban membayar pajak tergantung pada bagaimana citra aparat pajak dimata wajib pajak dan mutu pelayanan yang terbaik aparat pajak kepada wajib pajak (Jatmiko, 2006).

Berkaitan dengan kepercayaan terhadap aparat pajak, Maxwell (menurut Potter 1998 dalam supriyono 2001) mengungkapkan perlunya aparat pajak yang memiliki beberapa kriteria sebagai berikut :

a. Tepat dan relavan, artinya pelayanan harus mampu melebihi preferensi, harapan dan kebutuhan individu dan masyarakat.

b. Tersedia dan terjangkau, artinya pelayanan harus dapat dijangkau oleh setiap orang atau kelompok orang yang mendapat prioritas.

c. Dapat menjamin rasa keadilan, artinya terbuka dalam memberikan perlakuan terhadap individu atau sekelompok orang dalam keadaan yang sama.

d. Dapat diterima, artinya pelayanan memberikan kualitasapabiladilihatdariteknis/cara,kualitas, kemudahan, kenyamanan, menyenangkan, dapat diandalkan, tepat waktu, cepat, responsif dan manusiawi.

e. Ekonomis dan efisien, artinya dari sudut pandang pengguna pelayanan dapat dijangkau melalui tarif dan pajak oleh semua lapisan.

f. Efektif, artinya menguntungkan bagi pengguna dan semua lapisan masyarakat.

Meskipun aparat pajak diberi hak 
atau kewenangan untuk bertanggung jawab dalam keberhasilan pemungutan pajak, tetapi kewenangan setiap aparat pajak tersebut tetap dibatasi sesuai dengan jenjang jabatan pada instansi yang bersangkutan agar tidak terjadi penyalahgunaan kewenangan oleh aparat pajak yang dapat merugikan wajib pajak. Oleh karena itu seorang aparat pajak dalam menjalankan tugasnya harus ada penugasan resmi yang diberikan oleh pejabat yang berwenang. Dengan demikian apabila aparat pajak akan melakukan pemungutan terhadap wajib pajak atau instansi yang terkait harus dilengkapi dengan surat tugas dan tanda pengenal diri yang sah (Utami, 2016).

Aparat pajak yang baik, ramah, adil, dan tegas terhadap wajib pajak adalah dasar yang harus dimiliki aparat pajak dalam mendapatkan kepercayaan wajib pajak sehingga diharapkan dapat meningkatkan kepatuhan wajib pajak dalam menjalankan kewajibannya.

\section{Planned Behavior Theory}

Planned Behavior Theory atau yang lebih dikenal sebagai Theory of Planned Behavior menyatakan bahwa perilaku yang ditimbulkan oleh individu muncul karena adanya niat untuk berperilaku (Ajzen, 2006). Munculnya niat tersebut dikarenakan oleh tiga faktor, yaitu:

\section{a. Attitude Toward the Behavior.}

Attitude Toward the Behavior (sikap terhadap suatu perilaku) merupakan derajat penilaian positif atau negatif individu terhadap suatu perilaku. Attitude Toward the Behavior ditentukan oleh kombinasi antara beliefs individu mengenai konsekuensi positif atau negatif dari melakukan suatu perilaku (Behavioral Beliefs).

\section{b. Subjective Norm.}

Subjective Norm (norma subyektif tentang suatu perilaku) merupakan persepsi individu tentang tekanan sosial untuk melakukan atau tidak melakukan suatu perilaku. Subjective Norm ditentukan oleh kombinasi antara beliefs individu tentang harapan normatif orang lain dan motivasi untuk memenuhi harapan tersebut (Normative Beliefs).

c. Perceived Behavioral Control.
Perceived Behavior Control (persepsi tentang control perilaku) merupakan persepsi individu mengenai kemudahan atau kesulitan untuk melakukan suatu perilaku. Perceived Behavioral Control ditentukan oleh kombinasi antara beliefs individu mengenai faktor pendukung dan penghambat untuk melakukan suatu perilaku (Control Beliefs).

Teori ini menjelaskan perilaku wajib pajak dalam memenuhi kewajiban perpajakannya. Sebelum melakukan sesuatu, seseorang akan memiliki keyakinan mengenai hasil yang akan diperoleh dari perilakunya tersebut. Kemudian ia akan memutuskan bahwa akan melakukannya atau tidak. Seseorang yang taat pajak akan mengetahui pentingnya membayar pajak, karena ia memiliki keyakinan terhadap hasil yang diperoleh dari membayar pajak yang salah satunya untuk membantu menyelenggarakan pembangunan negara (Attitude Toward the Behavior).

Pada saat akan melakukan sesuatu seseorang akan memiliki persepsi tentang tekanan sosial untuk melakukan atau tidak melakukan suatu perilaku (Subjective Norm). Hal tersebut dapat dikaitkan dengan kepercayaan terutama terhadap aparat pajak, dimana dengan adanya citra yang baik dari aparat pajak dan sosialisasi perpajakan yang berkualitas memberikan dorongan kepada wajib pajak sehingga wajib pajak tersebut memiliki persepsi yang baik sehingga memilih perilaku taat pajak.

Sanksi pajak dibuat untuk mendukung agar wajib pajak mematuhi peraturan perpajakan. Kepatuhan wajib pajak akan ditentukan berdasarkan persepsi wajib pajak tentang seberapa kuat sanksi pajak mampu mendukung perilaku wajib pajak tersebut untuk taat pajak (Perceived Behavior Control).

Attitude Toward the Behavior, Subjective Norm, Perceived Behavior Control sebagai tiga faktor yang menentukan seseorang untuk berperilaku. Setelah terdapat tiga faktor tersebut, maka seseorang akan memasuki tahap intention, kemudian tahap terakhir adalah behavior. Tahap intention merupakan tahap dimana seseorang memiliki maksud atau niat untuk berperilaku, sedangkan behavior adalah tahap seseorang 
berperilaku (Ajzen, 2006). Tahap intention terkait dengan motivasi atau keinginan yang timbul dari dalam diri wajib pajak dan tahap behavior adalah tahap dimana wajib pajak kemudian merealisasikan keinginan tersebut yang dalam hal ini yaitu memenuhi kewajiban perpajakannya. Oleh karena itu, sosialisasi, sanksi, dan kepercayaan dapat menjadi faktor yang memotivasi wajib pajak dalam membayar pajak.

\section{Metode}

Model dan desain dalam penelitian ini adalah untuk memperoleh data tentang variabelvariabel yang mempengaruhi kepatuhan wajib pajak dalam membayar pajak PPh pasal21. Jenis penelitian yang digunakan dalam penelitian ini adalah penelitian eksperimen, yaitu penelitian yang menggunakan treatment berupa skenario data kuesioner. Sumber data yang digunakan adalah data subyek, yaitu data yang berupa opini, sikap, pengalaman atas karakteristik seseorang/ kelompok yang menjadi subyek penelitian (responden). Sedangkan data dalam penelitian ini adalah data primer, yaitu data yang diperoleh langsung dari sumber asli.

Populasi dalam penelitian ini adalah berjumlah 159.162 yaitu wajib pajak aktif yang membayar pajak $\mathrm{PPh}$ pasal 21 dan terdaftar di KPP Pratama Jakarta Kebayoran Lama. Sedangkan jumlah atau ukuran sampel yang akan digunakan dalam penelitian ini ditentukan dengan menggunakan rumus Slovin, dengan $\mathrm{e}^{2}=10 \%$ yaitu berjumlah 99,94 responden, tetapi untuk memudahkan dalam penelitian, maka jumlah sampel yang ditetapkan sebanyak 100 respoden (pembulatan).

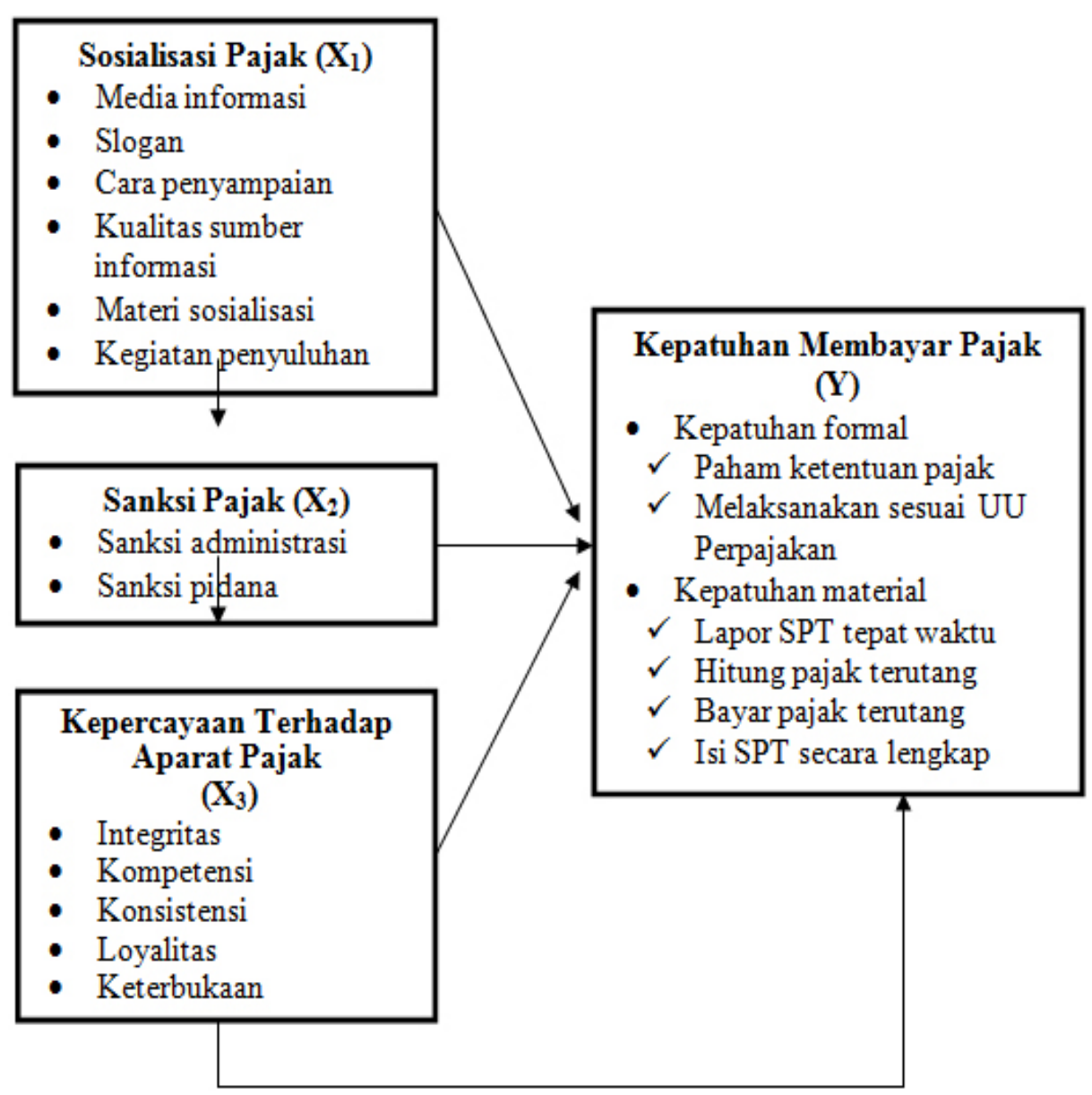

Gambar I. Kerangka Pemikiran Sosialisasi, Sanksi, dan Kepercayaan terhadap Kepatuhan Wajib Pajak dalam Membayar Pajak PPh Pasal 21 
Teknik pengambilan sampel yang digunakan dalam penelitian ini adalah nonprobability sampling dengan teknik pengambilan sampel secara Accidental Sampling (Convenience Sampling). Sugiono (2012) Accidental Sampling (Convenience Sampling) adalah tehnik penentuan sampel berdasarkan kebetulan, yaitu siapa saja yang secara kebetulan/insidental bertemu dengan peneliti dapat digunakan sebagai sampel, bila dipandang orang yang kebetulan ditemui itu cocok sebagai sumber data, yang dalam hal ini kriteria utamanya adalah wajib pajak orang pribadi yang membayar pajak penghasilan dan terdaftar di KPP Pratama Jakarta Kebayoran Lama..

Untuk melakukan pengujian hipotesis yang diajukan, variabel yang diteliti perlu diukur. Dalam penelitian ini, variabel - variabel penelitian terdiri dari variable eksogen dan variabel endogen. Variabel eksogen adalah "source variabel" atau "independent variabel" yang tidak diprediksi oleh variabel lain dalam model, sedangkan variabel endogen adalah variabel yang diprediksi oleh variabel lain. Sosialisasi Pajak

1) Variabel Sosialisasi . Sosialisasi perpajakan merupakan upaya Direktorat Jendral Pajak memberikan pengertian, informasi dan pembinaan kepada masyarakat pada umumnya dan wajib pajak pada khususnya mengenai segala sesuatu yang berhubungan dengan perpajakan dan perundang undangan (Saraswati, 2012). Surat Edaran Direktur Jendral Pajak Nomor SE-22/PJ./2007 tentang Penyeragaman Sosialisasi Perpajakan Bagi Masyarakat. Indikator sosialisasi perpajakan dalam penelitian ini terdiri dari:
a) Media informasi,
b) Slogan,
c) Cara penyampaian,
d) Kualitas sumber informasi,
e) Kegiatan penyuluhan.

2) Variabel Sanksi. Menurut Mardiasmo (2011) sanksi perpajakan merupakan jaminan bahwa ketentuan peraturan perundang-undangan perpajakan akan dipatuhi, atau bisa dengan kata lain sanksi perpajakan merupakan alat pencegah (preventif) agar wajib pajak tidak melanggar norma perpajakan. Sanksi pajak dapat diukur dengan indikator:

a) Sanksi administrasi, merupakan pembayaran kerugian negara, khususnya yang berupa denda, bunga, dan kenaikan.

b) Sanksi pidana, merupakan sanksi berupa siksaan atau penderitaan, merupakan suatu alat terakhir atau benteng hukum yang digunakan fiskus agar norma perpajakan dipatuhi.

3) Variabel Kepercayaan. Kepercayaan terhadap Aparat Pajak ialah ekspektasi wajib pajak terhadap ucapan dan tindakan aparat pajak yang dapat diandalkan dalam melayani, membantu, mengurus, atau menyiapkan segala keperluan yang dibutuhkan wajib pajak (Sulistyowati, 2012). Menurut Robbins (2006). Indikator kepercayaan terhadap aparat pajak terdiri :
a) Integritas,
b) Kompetensi,
c) Konsistensi,
d) Loyalitas,
e) Keterbukaan.

4) Variabel Kepatuhan. Menurut Lingga (2013), Devano dan Rahayu (2006) indikator dari kepatuhan perpajakan,yaitu:
a) Kepatuhan formal, dimana:
b) Wajib pajak sudah memahami semua ketentuan perpajakan,
c) Melaksanakannya sesuai dengan undang- undang perpajakan.
d) Kepatuhan material, yaitu kepatuhan kewajiban perpajakannya dalam:
e) Melaporkan SPT tepat waktu,
f) Menghitung pajak terutang,
g) Membayar pajak terutang sesuai dengan jumlahnya,
h) Mengisi SPT secara lengkap.

Data Penelitian yang akan dianalisis menggunakan alat analisis SPSS versi 23 yang terdiri dari: statistik deskriptif, uji kualitas data yaitu uji reliabilitas dan uji validitas, uji asumsi klasik, uji koefisien determinasi dan uji hipotesis dengan 
persamaan regresi berganda (multiple regression) yaitu sebagai berikut:

$$
\begin{aligned}
& \mathrm{Y}=\alpha+\beta 1 \mathrm{X} 1+\beta 2 \mathrm{X} 2+\beta 3 \mathrm{X} 3+\mathrm{e} \\
& \mathrm{Y}=6,746+0,035+0,052+0,370+\mathrm{e}
\end{aligned}
$$

Keterangan :

$\mathrm{Y}=$ Motivasi Wajib Pajak dalam

$X_{1}=$ Membayar Pajak PPh Pasal 21 Sosialisasi Pajak

$X_{2}=$ Sanksi Pajak

$X_{3}=$ Kepercayaan terhadap Aparat Pajak

$\mathrm{A}=$ Konstanta

$\mathrm{B}=$ Koefisien Regresi

$\mathrm{E}=$ Error

\section{Hasil Penelitian dan Pembahasan}

Responden dalam penelitian ini berjumlah 100 yang terdiri dari laki-laki yaitu sebanyak 55 responden (55\%), sedangkan perempuan sebanyak 45 responden (45\%). Berdasarkan lama memiliki NPWP, responden yang memiliki NPWP $<1$ tahun sebanyak 30 responden $(30 \%)$, responden yang memiliki NPWP selama 1-5 tahun sebanyak 32 responden $(32 \%)$, dan responden yang lama memiliki NPWP $>5$ tahun sebanyak 38 responden (38\%). Mengenai statistik deskripsi variable penelitian dapat dilihat tabel 3 dan 4 pada lampiran.

Uji kualitas data meliputi uji reliabilitas dan uji validitas menggunakan SPSS Ver.23. Uji reliabilitas dilakukan dengan uji Cronbach Alpha dengan nilai Cronbach Alpha $>0,60$ dan uji validitas dengan melihat Correlated item-Total Correlation $\mathrm{r}$ tabel product moment dengan signifikansi 10\%. Hasil uji reliabilitas menggunakan Cronbach's Alpha, semua alat ukur variabel dependen dalam penelitian ini, yang terdiri dari pelayanan aparat pajak, modernisasi sistem administrasi perpajakan, dan sanksi pajak serta variabel independen yaitu motivasi wajib pajak orang pribadi dalam membayar pajak penghasilan mempunyai nilai Cronbach's Alpha lebih besar dari 0,60. Hal tersebut menunjukkan bahwa alat ukur yang dipakai dalam penelitian ini adalah reliabel atau handal. Hasil dari uji validitas menunjukan bahwa semua nilai $r$ hitung lebih besar dari nilai $\mathrm{r}$ table prodeuct moment pada taraf signifikansi $10 \%$ dengan $\mathrm{df}=\mathrm{N}-2$, jadi dapat dihitung $\mathrm{df}=100-2=98$, maka dari hasil perhitungan tersebut dapat diketahui $\mathrm{r}$ - tabel $=$ 0,1654 sehingga dapat disimpulkan bahwa semua item pernyataan yang digunakan sebagai alat ukur dalam penelitian ini adalah valid. Mengenai statistik uji kualitas data penelitian dapat dilihat tabel $5,6,7,8,9,10,11,12,13,14$, dan 15 pada lampiran.

Pengujian asumsi klasik yang dilakukan dalam penelitian ini adalah uji normalitas dengan menggunakan analisis grafik (Normal Probability Plot), histogram, dan uji kolmogorov smirnov terhadap variabel dependen yang seluruhnya terdistribusi secara normal karena signifikansi melebihi 0,50 . Uji multikolonieritas terhadap variabel independen nilai tolerance menunjukkan tidak ada variabel independen yang memiliki tolerance kurang dari 0,10 (VIF dibawah 10) sehingga dapat disimpulkan bahwa semua konsep-konsep variabel tidak mengandung multikolinieritas. Sedangkan dari hasil uji heterokedastisitas dengan uji spearman's rho mengindikasikan nilai probabilitas signifikansinya di atas tingkat kepercayaan 10\% atau nilai signifikansi korelasinya lebih besar dari 0.10 , yang berarti dapat disimpulkan bahwa model regresi yang digunakan tidak mengandung heteroskedastisitas. Hasil uji heterokedasitas dengan menggunakan analisis grafik Scatterplot dapat diketahui bahwa tidak ada pola yang jelas, serta titik-titik menyebar secara acak serta tersebar baik diatas maupun dibawah angka 0 pada sumbu Y, maka dapat disimpulkan bahwa tidak terjadi heterokedastisitas pada model regresi, sehingga model regresi dinyatakan layak untuk digunakan. Mengenai hasil penelitian uji asumsi klasik dapat dilihat tabel 14,15,16 dan gambar 1,2, dan 3 pada lampiran.

Hasil dari uji koefisien determinasi dalam penelitian ini diketahui bahwa nilai Adjusted $R$ Square dari hasil pengolahan data sebesar $62,1 \%$ atau $(0,621)$. Hal ini menunjukkan variabel independen dalam pengaruhnya terhadap variabel dependen sebesar $62,1 \%$ dan sisanya dipengaruhi oleh faktor lain yang tidak diteliti yaitu $37,9 \%$ atau $(0,379)$. Mengenai statistik uji koefisien determinasi dalam penelitian ini dapt 
dilihat tabel 19 pada lampiran.

\section{Pengaruh Sosialisasi Pajak terhadap Kepatuhan Wajib Pajak dalam Membayar Pajak}

Hasil analisis membuktikan bahwa sosialisasi pajak tidak berpengaruh terhadap kepatuhan membayar pajak PPh pasal 21 pada KPP Pratama Jakarta Kebayoran Lama. Hal ini sejalan dengan faktor kegiatan penyuluhan kurang memiliki pengaruh yang signifikan terhadap kepatuhan membayar pajak, meskipun faktor-faktor sosialisasi pajak yang diukur dengan media informasi, slogan, cara penyampaian, kualitas sumber informasi, dan materi sosialisasi memiliki pengaruh yang signifikan terhadap kepatuhan wajib pajak dalam membayar pajak $\mathrm{PPh}$ pasal 21. Hal ini disebabkan karena sebagian besar wajib pajak tidak mau untuk mengikuti penyuluhan tentang perpajakan yang dilakukan aparat pajak. Akibatnya para wajib pajak biasanya menghindar untuk mengikuti penyuluhan. Akibatnya kegiatan penyuluhan tidak terlaksana dengan efektif.

Pada sub variabel lainnya yang diukur dengan media informasi berpengaruh signifikan terhadap kepatuhan membayar pajak, karena wajib pajak menyadari media informasi akan mampu membantu wajib pajak dalam memberikan informasi yang terkini dibidang perpajakan. Dengan demikian wajib pajak yang bersangkutan akan termotivasi untuk patuh membayar pajak.

Hasil analisis pada variabel sosialisasi pajak yang diukur dengan slogan dapat berpengaruh signifikan terhadap kepatuhan wajib pajak dalam membayar pajak PPh pasal 21. Hal ini disebabkan karena dengan slogan yang dipajang tidak menakut nakuti wajib pajak dan menekankan kepada manfaat pajak yang diperoleh. Dengan demikian ia dapat mempengaruhi wajib pajak agar termotivasi untuk patuh membayar pajaknya.

Hasil analisis pada variabel sosialisasi pajak yang diukur dengan cara penyampaian dapat berpengaruh signifikan terhadap kepatuhan wajib pajak dalam membayar pajak
PPh pasal 21. Hal ini disebabkan karena dengan cara penyampaian secara lansung kepada wajib pajak oleh aparat pajak serta dengan bahasa yang sesederhana mungkin sehingga informasi tersebut dapat diterima dengan baik. Dengan demikian ia dapat mempengaruhi wajib pajak agar termotivasi untuk patuh membayar pajaknya.

Hasil analisis pada variabel sosialisasi pajak yang diukur dengan kualitas sumber informasi dapat berpengaruh signifikan terhadap kepatuhan wajib pajak dalam membayar pajak PPh pasal 21. Hal ini disebabkan karena sumber informasi seperti televisi, call center, internet, aparat pajak, radio, dan koran bisa dipercaya dan dipertanggung jawabkan serta bisa menjadi sumber informasi yang informatif dan berkualitas. Dengan demikian ia dapat mempengaruhi wajib pajak agar termotivasi untuk patuh membayar pajaknya.

Hasil analisis pada variabel sosialisasi pajak yang diukur dengan materi sosialisasi dapat berpengaruh signifikan terhadap kepatuhan wajib pajak dalam membayar pajak PPh pasal 21. Hal ini disebabkan karena materi sosialisasi yang disampaikan jelas dan mudah dimengerti dan ditekankan terutama pada manfaat pajak, manfaat NPWP dan pelayanan perpajakan. Dengan demikian dapat mempengaruhi wajib pajak agar termotivasi untuk patuh membayar pajaknya. Maka secara garis besar mengenai variabel sosialisasi pajak dapat disimpulkan bahwa semakin tinggi sosialisasi pajak yang dilakukan oleh aparat pajak KPP Pratama Jakarta Kebayoran Lama maka semakin meningkat kepatuhan wajib pajak untuk membayar pajak PPh pasal 21 pada KPP tersebut. Wajib pajak akan melaporkan, menghitung dan membayarkan pajak jika memiliki pengetahuan yang baik tentang perpajakan.

\section{Pengaruh Sanksi Pajak terhadap Kepatuhan Wajib Pajak dalam Membayar Pajak}

Hasil analisis dalam tabel 17 pada lampiran membuktikan bahwa sanksi pajak tidak berpengaruh terhadap kepatuhan wajib pajak dalam membayar pajak PPh pasal 21 pada KPP Pratama Jakarta Kebayoran Lama, meskipun 
faktor sanksi pajak yang diukur dengan sanksi pidana memberikan pengaruh yang signifikan terhadap kepatuhan wajib pajak dalam membayar pajak. Hal ini disebabkan karena pemberian sanksi administrasi yang masih dianggap ringan oleh wajib pajak, sehingga wajib pajak cenderung mengabaikan sanksi administrasi tersebut. Dengan demikian, wajib pajak tidak segan apabila telat membayar bahkan tidak membayar dan melaporkan pajak sama sekali.

Selain itu variabel sanksi pajak yang diukur dengan sanksi pidana berpengaruh positif dan signifikan terhadap motivasi wajib pajak orang pribadi dalam membayar pajak. Hal ini disebabkan karena sanksi pidana merupakan hukuman yang sangat berat dalam perpajakan, cenderung tidak dapat dinegoisasi dan memberi efek jera bagi wajib pajak. Oleh karena itu wajib pajak merasa takut akan sanksi pidana yang akan diterimanya apabila ia melanggar ketentuan perpajakan, maka dengan demikian wajib pajak orang pribadi tersebut akan taat dan termotivasi untuk membayar pajak.

Maka secara garis besar mengenai variabel sanksi perpajakan dapat disimpulkan bahwa sanksi yang diberikan tidak akan meningkatkan kepatuhan wajib pajak orang pribadi dalam membayar pajak PPh pasal 21 . Hal ini disebabkan karena pemberian sanksi yang masih dianggap ringan, sehingga wajib pajak cenderung mengabaikan sanksi tersebut. Dengan demikian, wajib pajak tidak takut apabila telat membayar bahkan tidak membayar dan melaporkan pajak sama sekali.

\section{Pengaruh Kepercayaan Terhadap Aparat Pajak dalam Kepatuhan Membayar Pajak}

Hasil analisis dalamtabel 17 pada lampiran membuktikan bahwa kepercayaan terhadap aparat pajak berpengaruh signifikan terhadap kepatuhan wajib pajak dalam membayar pajak PPhpasal 21 pada KPP Pratama Jakarta Kebayoran Lama, meskipun faktor-faktor kepercayaan terhadap aparat pajak yang diukur dengan keterbukaan, kurang memberikan pengaruh yang signifikan terhadap kepatuhan wajib pajak dalam membayar pajak PPh pasal 21. Hal ini disebabkan karena sebagian besar wajib pajak menilai aparat pajak kurang terbuka dalam aliran masuk dari berbagai sumber penerimaan pajak dan dalam pengelolaan serta pendistribusian dana pajak. Hal itu jelas terlihat bahwa sub variabel keterbukaan kurang membuat wajib pajak patuh.

Hasil analisis pada variabel kepercayaan terhadap aparat pajak yang diukur dengan integritas dapat berpengaruh signifikan terhadap kepatuhan wajib pajak dalam membayar pajak PPh pasal 21. Hal ini disebabkan karena dengan aparat pajak yang jujur dan bertanggung jawab serta bertindak sesuai kode etik yang berlaku dapat mempengaruhi wajib pajak agar termotivasi untuk patuh membayar pajaknya.

Hasil analisis pada variabel kepercayaan terhadap aparat pajak yang diukur dengan kompetensi dapat berpengaruh signifikan terhadap kepatuhan wajib pajak dalam membayar pajak PPh pasal 21. Hal ini disebabkan karena aparat pajak memiliki kecerdasan interpesonal (kecerdasan sosial) dalam menjalani hubungan yang baik dengan wajib pajak serta memiliki pengetahuan dan keterampilan teknis dalam melayani setiap kepentingan wajib pajak, sehingga dapat mempengaruhi wajib pajak agar termotivasi untuk patuh membayar pajaknya.

Hasil analisis pada variabel kepercayaan terhadap aparat pajak yang diukur dengan konsistensi dapat berpengaruh signifikan terhadap kepatuhan wajib pajak dalam membayar pajak $\mathrm{PPh}$ pasal 21. Hal ini disebabkan karena aparat pajak mempunyai pandangan yang baik dan konsisten dalam menangani permasalahan wajib pajak sehingga dapat mempengaruhi wajib pajak agar termotivasi untuk patuh membayar pajaknya.

Hasil analisis pada variabel kepercayaan terhadap aparat pajak yang diukur dengan loyalitas dapat berpengaruh signifikan terhadap kepatuhan wajib pajak dalam membayar pajak $P P h$ pasal 21. Hal ini disebabkan karena aparat pajak tidak bertindak menguntungkan diri sendiri dan patuh terhadap peraturan undang-undang perpajakan sehingga dapat mempengaruhi wajib pajak agar termotivasi untuk patuh membayar pajaknya. 
Maka secara garis besar mengenai variabel kepercayaan terhadap aparat pajak dapat disimpulkan bahwa semakin tinggi kepercayaan terhadap aparat pajak pada KPP Pratama Jakarta Kebayoran Lama maka semakin meningkat kepatuhan wajib pajak untuk membayar pajak PPh pasal 21 pada KPP tersebut. Wajib pajak akan melaporkan, menghitung dan membayarkan pajak jika memiliki kepercayaan yang baik terhadap aparat pajak. Penelitian ini sejalan dengan penelitian yang dilakukan oleh Putri (2013), pada penelitian di KPP Pratama Batu, menemukan bahwa variabel kepercayaan terhadap aparat pajak memiliki pengaruh positif dan signifikan terhadap kepatuhan pemilik UMKM dalam memiliki NPWP.

Meskipun faktor-faktor kepatuhan wajib pajak dalam membayar pajak yang diukur dengan kegiatan penyuluhan, sanksi administrasi, dan keterbukaan kurang memberi pengaruh yang signifikan, namun ke sepuluh sub variabel lainnya yang diukur dengan media informasi, slogan, cara penyampaian, kualitas sumber informasi, materi sosialisasi, sanksi pidana, integritas, kompetensi, konsistensi, dan loyalitas secara bersama-sama dapat mempengaruhi kepatuhan wajib pajak dalam membayar pajak $\mathrm{PPh}$ pasal 21 pada KPP Pratama Jakarta Kebayoran Lama secara signifikan.

Dengan demikian, untuk meningkatkan kepatuhan wajib pajak yang membayar pajak PPh pasal 21 dan terdaftar di KPP Pratama Jakarta Kebayoran Lama, para aparat pajak harus meningkatkan kegiatan penyuluhan yang diiberikan kepada wajib pajak tersebut, meningkatkan sanksi perpajakan dengan menindak tegas para pelanggar ketentuan pajak, serta meningkatkan keterbukaan aliran masuk dan pendistribusian dana pajak.

\section{Simpulan, Keterbatasan, dan Implikasi Hasil Penelitian}

Berdasarkan pada hasil penelitian yang telah diuraikan pada bagian sebelumnya, maka dapt diperoleh kesimpulan sebagai berikut : Pertama. Secara parsial membuktikan bahwa variabel Sosialisasi Pajak yang diukur dengan media informasi, slogan, cara penyampaian, kualitas sumber informasi, materi sosialisasi, dan kegiatan penyuluhan tidak berpengaruh terhadap kepatuhan membayar pajak PPh pasal 21 pada KPP Pratama Kebayoran Lama. Kedua. Secara parsial membuktikan bahwa variabel sanksi pajak yang diukur dengan sanksi administrasi dan sanksi pidana tidak berpengaruh terhadap kepatuhan membayar pajak PPh pasal 21 pada KPP Pratama Kebayoran Lama. Ketiga. Secara parsial membuktikan bahwa variabel kepercayaan terhadap aparat pajak yang diukur dengan integritas, kompetensi, konsistensi, loyalitas, dan keterbukaan berpengaruh positif dan signifikan terhadap kepatuhan membayar pajak $\mathrm{PPh}$ pasal 21 pada KPP Pratama Kebayoran Lama. Keempat. Secara simultan membuktikan bahwa seluruh variabel independen yaitu Sosialisasi Pajak, Sanksi Pajak, dan Kepercayaan Terhadap Aparat Pajak berpengaruh positif dan signifikan terhadap kepatuhan membayar pajak PPh pasal 21 pada KPP Pratama Kebayoran Lama.

Berdasarkan penelitian yang dilakukan ini ada beberapa saran yang mungkin berguna : Pertama. bagi Instansi Pemerintahan yang dalam hal ini otoritas pajak, hendaknya memperhatikan faktor-faktor yang mempengaruhi wajib pajak dalam memenuhi kewajiban perpajakannya terutama mengenai faktor kepercayaan terhadap aparat pajak, karena faktor tersebut berpengaruh terhadap kepatuhan wajib pajak dalam membayar pajak terutama wajib pajak yang membayar pajak $\mathrm{PPh}$ pasal 21. Sehingga dengan diberikannya kepercayaan kepada para wajib pajak, dapat membantu meningkatkan kepatuhan para wajib pajak tersebut. Kedua. Bagi wajib pajak, untuk lebihmeningkatkankepatuhandalammenjalankan kewajiban pajak, yaitu membiasakan diri untuk patuh dan taat akan kewajiban perpajakannya. Ketiga. Peneliti selanjutnya diharapkan dapat menambahkan variabel independen lainnya atau menambahkan variabel moderating untuk mengetahui variabel-variabel lain yang dapat mempengaruhi variabel dependen. Penelitian selanjutnya juga dapat mengembangkan atau menambahkan daftar pernyataan yang ada dan 
tidak hanya menggunakan data kuesioner, tetapi dapat dilakukan wawancara terhadap responden agar validitas data yang lebih baik. Selain itu dapat menambah jumlah sampel penelitian serta memperluas wilayah sampel penelitian, tidak hanya di KPP Pratama Jakarta Kebayoran Lama saja tetapi juga di KPP lainnya, sehingga dapat diperoleh hasil penelitian dengan tingkat generalisasi yang lebih tinggi.

\section{Daftar Rujukan}

2014. Laporan Kinerja

Kementrian Keuangan (URL: www.kemenkeu. go.id, diakses 1 Maret 2016).

2014. Laporan Tahunan

Direktorat Jenderal Pajak (URL: www. pajak.go.id, diakses 1 Maret 2016).

Rutiyaningsih, Sri. 2011. Faktor-faktor yang Mempengaruhi Kepatuhan Wajib Pajak. Wydia Warta No. 2 Tahun XXXV, Juli 2011, Hal 44-54.

Lingga, Salsalina Ita. 2013. Pengaruh Peneraan e-SPT terhadap Kepatuhan Pajak. Jurnal Akuntansi, Vol. 5 No. 1, Mei 2013. Hal 50-60.

Devano, Sony dan Rahayu, Siti. 2006.Perpajakan: Konsep Teori dan Isu. Jakarta: Prenada Media Group.

. Undang-Undang Republik Indonesia Nomor 16 Tahun 2000 tentang Ketentuan Umum dan Tata Cara Perpajakan. Jakarta: Berita Pajak.

Utami, Tyas Erasari. 2016. Pengaruh Pelayanan Aparat Pajak, Modernisasi Sistem Administrasi Perpajakan, dan Sanksi Pajak terhadap Motivasi Wajib Pajak Orang Pribadi dalam Membayar Pajak Penghasilan. Skripsi Universitas Prof. Dr. Moestopo (Beragama). Jakarta.

Anies. S, Basamalah. 2004. Perilaku Organisasi Memahami dan Mengelolah Aspek Humaniora dalam Organisasi. Edisi 3. Depok: Usaha Kami.

Saraswati, Anggun Kurnia. 2012. Analisis FaktorFaktor yang Mempengaruhi Kepatuhan Wajib Pajak Badan. Skripsi Universitas
Diponegoro. Semarang. . Surat Edaran Direktur Jenderal Pajak Nomor SE-22/PJ/2007 Tentang Penyeragaman Sosialisasi Perpajakan bagi Masyarakat.

Mardiasmo. Perpajakan. Edisi Revisi 2011. 2011. Yogyakarta: Andi. . Undang-Undang Ketentuan Umum dan Tata Cara Perpajakan tentang Sanksi.

Yulianto, Gatot dan Waluyo, Purwanto. 2004. Pengaruh Keefektifan Komunikasi, Kualitas Tekhnikal, Kualitas Fungsional dan Nilai Pelanggan pada Komitmen Ketrhubungan pada Bandara Ahmad Yani Semarang. Telaah Manajemen, Magister STIE Stikubank Semarang, Vol. 1, Edisi 3, 2004.

Sulistyowati, Endah. 2012. Implementasi Kurikulum Pendidikan Karakter. Yogyakarta: Citra Adi Parama.

Robbins, Stephen. 2006. Perilaku Organisasi. Edisi 10. Klaten: Indeks Gramedia.

Jatmiko, Agus. N. 2006. Pengaruh Sikap Wajib Pajak pada Pelaksanaan Sanksi Denda, Pelayanan Fiskus dan Kesadaran Perpajakan terhadap Kepatuhan Wajib Pajak. Tesis Universitas Diponegoro. Semarang.

Supriyono, R.A. 2001. Akuntansi Manajemen. Edisi Pertama. Yogyakarta: BPFE.

Ajzen, I. 2006. Behavioral Interventions Based on the Theory of Planned Behavior. Milton Keynes: Open University Press.

Sugiyono. 2012. Metode Penelitian Kuantitatif Kualitatif dan R\&D. Bandung: Alfabeta. 